\title{
The effect of stocking rate on soil solution nitrate concentrations beneath a free-draining dairy production system in Ireland
}

\author{
J. McCarthy, ${ }^{*} †$ L. Delaby, D. Hennessy, ${ }^{*}$ B. McCarthy, ${ }^{*}$ W. Ryan, ${ }^{*}$ K. M. Pierce,† A. Brennan, ${ }^{*}$ and B. Horan* \\ ${ }^{*}$ Animal and Grassland Research and Innovation Centre, Teagasc Moorepark, Fermoy, Co. Cork, Ireland \\ †School of Agriculture, and Food Science, University College Dublin, Belfield, Dublin 4, Ireland \\ łINRA, AgroCampus Ouest, UMR 1348, Physiologie, Environnement et Génétique pour l'Animal et les Systèmes d'Elevage, \\ F-35590 Saint-Gilles, France
}

\section{ABSTRACT}

Economically viable and productive farming systems are required to meet the growing worldwide need for agricultural produce while at the same time reducing environmental impact. Within grazing systems of animal production, increasing concern exists as to the effect of intensive farming on potential $\mathrm{N}$ losses to ground and surface waters, which demands an appraisal of $\mathrm{N}$ flows within complete grass-based dairy farming systems. A 3 -yr (2011 to 2013) whole-farm system study was conducted on a free-draining soil type that is highly susceptible to $\mathrm{N}$ loss under temperate maritime conditions. Soil solution concentrations of N from 3 spring-calving, grass-based systems designed to represent 3 alternative whole-farm stocking rate (SR) treatments in a post-milk quota situation in the European Union were compared: low (2.51 cows/ha), medium (2.92 cows/ ha), and high SR (3.28 cows/ha). Each SR had its own farmlet containing 18 paddocks and 23 cows. Nitrogen loss from each treatment was measured using ceramic cups installed to a depth of $1 \mathrm{~m}$ to sample the soil water. The annual and monthly average nitrate, nitrite, ammonia, and total $\mathrm{N}$ concentrations in soil solution collected were analyzed for each year using a repeated measures analysis. Subsequently, and based on the biological data collated from each farm system treatment within each year, the efficiency of $\mathrm{N}$ use was evaluated using an $\mathrm{N}$ balance model. Based on similar $\mathrm{N}$ inputs, increasing SR resulted in increased grazing efficiency and milk production per hectare. Stocking rate had no significant effect on soil solution concentrations of nitrate, nitrite, ammonia, or total $\mathrm{N}(26.0,0.2,2.4$, and $32.3 \mathrm{mg} / \mathrm{L}$, respectively). An $\mathrm{N}$ balance model evaluation of each treatment incorporating input and output data indicated that the increased grass utilization and milk production per hectare at higher SR resulted in a

Received August 1, 2014.

Accepted February 19, 2015.

${ }^{1}$ Corresponding author: brendan.horan@teagasc.ie reduction in $\mathrm{N}$ surplus and increased $\mathrm{N}$ use efficiency. The results highlight the possibility for the sustainable intensification of grass-based dairy systems and suggest that, at the same level of $\mathrm{N}$ inputs, increasing SR has little effect on $\mathrm{N}$ loss in pastoral systems with limited imported feed. These results suggest that greater emphasis should be attributed to increased grass production and utilization under grazing to further improve the environmental impact of grazing systems.

Key words: stocking rate, grass utilization, nitrate leaching, milk production

\section{INTRODUCTION}

During the next half century, global agricultural production faces 2 fundamental challenges: to produce enough food for the growing numbers of, on average, increasingly affluent and longer living people, and simultaneously preserve natural resources and the environment. Current figures estimate that $26 \%$ of global land area is covered by grasslands, which provide an important feed source for livestock and contributes positively to environmental protection (FAO, 2014). Consequently, it is essential that improvements in productivity are achieved within grassland agriculture but, without adverse effects on the natural environment. The process of producing more food, while reducing the environmental impact of dairy production systems, has become a global challenge and requires what has been referred to as sustainable intensification (Pretty, 1997; Royal Society, 2009) of global agricultural production. Despite the positive effect of $\mathrm{N}$ fertilizer use on agricultural production (Whitehead, 1995), the efficiency with which $\mathrm{N}$ is used is variable (Watson and Atkinson, 1999). As N moves within grassland systems, unavoidable losses occur through 3 major loss pathways: $\mathrm{NO}_{3}{ }^{-}$leaching, $\mathrm{N}_{2} \mathrm{O}$ emissions, and $\mathrm{NH}_{3}$ volatilization (Whitehead, 1995). In recent years, agricultural production systems within the European Union (EU) have increasingly been subjected to stringent environmental restrictions to reduce losses of bioavailable forms of $\mathrm{N}$ to water and air (Stark 
and Richards, 2008; Richards et al., 2009). Grazing is accompanied by localized deposition of $\mathrm{N}$ in urine and dung patches, which can contribute to environmental $\mathrm{N}$ pollution either as $\mathrm{NH}_{3}$ and $\mathrm{N}$ oxides in air or as $\mathrm{NO}_{3}{ }^{-}$ in soil and ground water (Tamminga, 1992). Nitrate leaching losses are problematic within grazing systems (Haynes and Williams, 1993; Ledgard et al., 1999), as elevated $\mathrm{N}$ applications via urine deposition by grazing animals is poorly attenuated within the soil (Haynes and Williams, 1993; Decau et al., 1997).

Within the EU, the abolition of milk quotas in April 2015 is anticipated to result in a redistribution of regional milk production (Lips and Reider, 2005). By virtue of lower production costs, milk production from grass-based systems in Ireland and northwest Europe are anticipated to expand based on the production and utilization of increased quantities of high-quality grass (Lips and Reider, 2005; O'Donnell et al., 2008; DAFM, 2011). Stocking rate (SR; cows/ha), defined as the number of animals per unit area of land used during a specified period of time, is well accepted as the main driver of productivity within grazing systems (Hoden et al., 1991; Macdonald et al., 2008; McCarthy et al., 2011), and recent studies have highlighted the beneficial effects of a high SR on animal productivity, grazed grass utilization, and overall farm system efficiency (Kelly et al., 2012; McCarthy et al., 2013a). Notwithstanding these beneficial effects, previous studies have also indicated that where increased SR are associated with increased chemical fertilizer $\mathrm{N}$ application and off-farm supplementary feed importation, N surpluses increase and $\mathrm{N}$ utilization is reduced, resulting in increased $\mathrm{N}$ loss to ground water and the general environment (Di and Cameron, 2002a; Treacy et al., 2008; Ryan et al., 2011).

Previous studies have identified the necessity to reduce $\mathrm{N}$ output through animal excretions by improving $\mathrm{N}$ utilization by the animal (Jonker et al., 1998). However, the opportunity to mitigate $\mathrm{N}$ losses are considerably reduced within grazing systems where a large proportion of the total diet consists of grazed grass (Dillon et al., 2005) and $\mathrm{N}$ utilization of grazing animals is often lower than 25\% (Tas et al., 2006; Jarvis et al., 2011). From an overall farm systems perspective, previous studies have highlighted excessive $\mathrm{N}$ inputs in fertilizer and feed supplements, heterogeneous $\mathrm{N}$ deposition on the available area, and the cultivation of high$\mathrm{N}$ soils as key reasons for inefficient $\mathrm{N}$ use (Gourley et al., 2012). Consequently, increasing international emphasis has focused on various $\mathrm{N}$ fertilizer application, animal, dietary, sward, and soil manipulation strategies to reduce $\mathrm{NO}_{3}^{-} \mathrm{N}$ loss (Di and Cameron, 2002b; Moir et al., 2012; O'Connor et al., 2013). In practice, how- ever, it is not possible to implement a combination of individual management effects, as these are interrelated within an overall system and there remains a paucity of quantitative data on $\mathrm{N}$ losses from intensive farming systems incorporating best practice $\mathrm{N}$ and grazing management practices. In response to this information gap, a 3-yr field experiment was uniquely designed to investigate the effect of overall farm SR on $\mathrm{N}$ use efficiency within intensive grass-based production systems. Consequently, the objective of the current study was to evaluate the effect of alternate whole-farm grass-based $\mathrm{SR}$ on $\mathrm{N}$ loss beneath a free-draining soil type within farming systems based on highly productive grassland swards combined with best practice grazing and $\mathrm{N}$ management over 3 consecutive years. The hypothesis of our study was that increases in overall farm system $\mathrm{SR}$ would have no deleterious effect on $\mathrm{N}$ losses in soil solution to $1 \mathrm{~m}$ of soil depth where the increased SR was derived from increased grazed grass utilization, based on fixed $\mathrm{N}$ inputs, and best practice agronomic and $\mathrm{N}$ management practices.

\section{MATERIALS AND METHODS}

\section{Site Characteristics}

The experiment was conducted over a 3 -yr period (2011 to 2013) on a permanent grassland site at Curtins Research Farm, Teagasc, Animal \& Grassland Research and Innovation Centre, Moorepark, Fermoy, Co. Cork, Ireland $\left(52^{\circ} 9^{\prime} \mathrm{N}, 8^{\circ} 16^{\prime} \mathrm{W}\right)$. The area has a mild moist oceanic climate without extremes in temperature. The soil on site (to a depth of $2.5 \mathrm{~m}$ ) is a freely drained acid brown earth, derived from mixed sandstone-limestone glacial till overlying a karstified limestone bedrock aquifer with bedrock commonly occurring at an average of $2.5 \mathrm{~m}$ below the ground surface (Bartley and Johnston, 2006; Gibbons et al., 2006). This site is representative of soils vulnerable to $\mathrm{NO}_{3}{ }^{-}$leaching, and represents between 4 and 10\% of the riskier soils in Ireland (Ryan et al., 2006). The on-site swards were predominantly perennial ryegrass (Lolium perenne L.) and had been reseeded over the previous 1 to $9 \mathrm{yr}$.

\section{Experimental Design, Treatments, and Herd Management}

The current experiment formed part of a larger study designed to examine the biological and economic effect of SR in the context of the removal of EU milk quotas; a more detailed description of the animals, treatment, and experimental design has previously been reported (McCarthy et al., 2013b). In spring 2011, 138 high Eco- 
nomic Breeding Index, spring-calving Holstein Friesian dairy cows were randomly assigned, precalving, based on parity, expected calving date, and Economic Breeding Index to 1 of 3 whole-farm SR treatments: low (2.51 cows/ha; LSR), medium (2.92 cows/ha; MSR) and high (3.28 cows/ha; HSR). Treatments were designed to represent alternative whole-farm SR which may be appropriate in a post-milk quota EU, spring-calving, grass-based milk production system. The experimental herd on the study comprised genetically elite animals (McCarthy et al., 2013b) and were managed with a compact spring-calving pattern that was closely aligned with the average grass growth capacity of the site $(50 \%$ of all animals calving in the first 2 wk of February, $90 \%$ calved by mid-March; mean calving date of February $20)$. As a grass-based production system, grazing commenced as cows calved in early February and the grazing season concluded in late November of each year. During December and January, all cows were dried off and housed on a diet of conserved grass silage.

\section{Grazing, Feeding, and Nutrient Management}

A total of 48.1 ha of permanent grassland, containing greater than $80 \%$ perennial ryegrass, were used for the duration of the experiment. Eighteen blocks were created, balanced on location, sward age, and soil type. Within each block, paddocks were randomly assigned to SR treatment to create a farmlet for each treatment, and paddocks remained in the same treatment farmlet for the duration of the experiment. Total farmlet areas for the LSR, MSR, and HSR were 9.17, 7.87, and 7.01 ha, respectively. Grazing management was accomplished by weekly monitoring of farm grass cover within each SR treatment (O'Donovan, 2000). To apply the SR effect consistently between paddocks, the residency time within each paddock, ranging from 1.5 to $2.5 \mathrm{~d}$ per paddock, was determined by achieving the target postgrazing residual sward height $(\mathrm{LSR}=4.5$ to $5.0 \mathrm{~cm}, \mathrm{MSR}=4.0$ to $4.5 \mathrm{~cm}$, and HSR 3.5 to $4.0 \mathrm{~cm}$ ). Each group was moved independently of one another to the next paddock once the target postgrazing residual sward height was reached. Rotation lengths during the main grazing season (April to August) were also allowed to vary between SR treatments. When pregrazing herbage mass in the next grazing paddock exceeded the target level, the paddock was skipped and herbage was harvested as silage. All silage was conserved in bales $(259 \pm 44.7 \mathrm{~kg}$ of DM). A sample of herbage was taken before baling for DM determination and bales from each paddock were weighed to give an estimate of the amount of feed conserved from each paddock (Macdonald et al., 2008). No mechanical topping of the swards took place during the experiment.
Best practice nutrient and agronomic management was applied to the management of each farmlet within the study and has been reported previously by Huebsch et al. (2013). Chemical N fertilizer (a combination of urea and calcium ammonium nitrate, depending on the time of year) application rates were common across SR treatments at $250 \mathrm{~kg}$ of $\mathrm{N} /$ ha per year and were applied according to recommended rates and timings (Teagasc, 2009). During the winter months between late November and early February, all animals were housed and all animal slurry was collected and stored. During periods of excessive rainfall during the grazing season, animals were occasionally housed and on-off grazing (Kennedy et al., 2009) was used as a management tool to facilitate grazing and to avoid soil structural damage.

All animal slurry generated by the animals during winter was reapplied to each farmlet over the first 4 mo of the following grazing season and at a rate consistent with the overall SR of each farmlet. As the experiment was designed to maintain similar $\mathrm{N}$ inputs to each $\mathrm{SR}$ treatment, target concentrate supplementation was similar for each SR at $850 \mathrm{~kg}$ of DM/ha per year and, consequently, lower per cow as SR increased. The ingredient composition of the concentrate feed was $25 \%$ barley, $26 \%$ corn gluten, $35 \%$ beet pulp, $11 \%$ soybean meal, and $3 \%$ minerals plus vitamins. Mean concentrate quality was $14.0 \% \mathrm{CP}, 27.0 \% \mathrm{NDF}, 8.1 \%$ crude fiber, and $9.6 \%$ ash. Mean silage quality was $15.1 \% \mathrm{CP}$, $55.3 \% \mathrm{NDF}, 37.8 \% \mathrm{ADF}$, and $9.4 \%$ ash.

Concentrate supplementation for all treatments commenced at $4 \mathrm{~kg} / \mathrm{cow}$ per day postcalving, and it was reduced and removed totally from the diet only when herbage supply exceeded animal demand for all treatments (usually in mid-March). Concentrate and additional forage supplementation (in the form of baled silage) were used occasionally during the 3-yr study when grass supply was in deficit of feed demand. Concentrate supplement was only used when a feed deficit occurred, due to reductions in grass growth, for each SR treatment and at a similar rate per hectare in all treatments on those occasions. When feed deficits arose for individual SR treatments, conserved forage produced within each treatment was used to supplement feed supply.

\section{Milk Production Measurements}

Cows were milked twice daily throughout lactation across the 3 yr of the study. Milking took place at 0700 and $1530 \mathrm{~h}$ daily. Weekly milk production was derived from individual cow milk yield $(\mathrm{kg})$ recorded at each milking (Dairymaster, Causeway, Co. Kerry, Ireland). Milk fat, protein, and lactose concentrations were determined in successive evening and morning samples 
of milk each week using Milkoscan 203 (Foss Electric, Hillerød, Denmark) and weekly fat, protein, and lactose yields were calculated.

\section{Herbage Measurements}

Grazing data were collected on each paddock during each grazing rotation according to the procedures outlined by McCarthy et al. (2013a). Pregrazing herbage mass $(>3.5 \mathrm{~cm})$ was determined before grazing on each paddock for each of the 3 systems by harvesting 2 strips $(1.2 \times 10 \mathrm{~m})$ of grass with an Etesia mower (Etesia UK Ltd., Warwick, UK). All mown herbage from each strip was collected and weighed and a $0.1-\mathrm{kg}$ (fresh weight) subsample was taken and dried for $16 \mathrm{~h}$ at $90^{\circ} \mathrm{C}$ for $\mathrm{DM}$ determination. Ten compressed sward-height (CSH) measurements were recorded before and after harvesting on each cut strip using a rising pasture plate meter with a steel plate (Jenquip, Feilding, New Zealand). Based on the above measurements, sward density was calculated as (Delaby and Peyraud, 1998):

$$
\begin{gathered}
\text { Sward density }(\mathrm{kg} \text { of } \mathrm{DM} / \mathrm{cm} \text { per hectare })= \\
\text { herbage mass }(\mathrm{kg} \text { of } \mathrm{DM} / \mathrm{ha}) /(\text { precutting } \mathrm{CSH} \\
- \text { postcutting } \mathrm{CSH}) .
\end{gathered}
$$

Pre- and postgrazing sward height was determined on each paddock before and after grazing by taking between 30 and 50 measurements across the diagonal of the paddock. The average paddock pregrazing herbage mass above a cutting height of $3.5 \mathrm{~cm}$ ( $\mathrm{kg}$ of DM/ha) was then calculated according to the following formula

$$
\begin{gathered}
\text { Pregrazing herbage mass }(\mathrm{kg} \text { of DM/ha })= \\
\text { [pregrazing CSH }(\mathrm{cm})-3.5 \mathrm{~cm}] \times \text { sward density }
\end{gathered}
$$

( $\mathrm{kg}$ of $\mathrm{DM} / \mathrm{cm}$ per hectare).

Herbage used at each grazing was calculated using the following formula (Delaby and Peyraud, 1998):

$$
\begin{gathered}
\text { Herbage used }(\mathrm{kg} \text { of } \mathrm{DM} / \mathrm{ha})=(\text { pregrazing } \mathrm{CSH} \\
- \text { postgrazing } \mathrm{CSH}) \times \text { sward density } \\
(\mathrm{kg} \text { of } \mathrm{DM} / \mathrm{cm} \text { per hectare })
\end{gathered}
$$

The efficiency of grazing was determined using the method proposed by Delaby and Peyraud (1998; herbage used/pregrazing herbage mass $(>3.5 \mathrm{~cm}$, at each grazing). Herbage accumulation between grazings was calculated as the difference between pregrazing herbage mass $(>3.5 \mathrm{~cm})$ and the postgrazing herbage mass of the previous rotation. Herbage used (above the postgrazing $\mathrm{CSH}$ ) was calculated within the same rotation as defined previously. Total herbage accumulation and herbage use was calculated as the sum of the herbage accumulated and used at each grazing for each treatment. Daily grass regrowth was calculated by dividing the herbage accumulated between grazings by the intergrazing interval.

\section{Chemical Analyses}

Herbage samples were collected from each paddock before grazing for each treatment and were dried at $40^{\circ} \mathrm{C}$ for $48 \mathrm{~h}$ and milled through a $1-\mathrm{mm}$ sieve. Samples were bulked by SR treatment by week and were subsequently analyzed for CP content (Leco FP-428; Leco Australia Pty Ltd., Baulkham Hills, New South Wales, Australia). Subsequently, herbage N content was calculated as $\mathrm{CP} \times 0.16$.

\section{Meteorological Data}

Daily measurements of average, minimum, and maximum air temperatures, total solar radiation, and daily rainfall were recorded automatically by a meteorological station approximately $3 \mathrm{~km}$ from the experimental site at the Animal and Grassland Research and Innovation Centre, Teagasc, Moorepark, Fermoy, Co. Cork. Weekly effective drainage (ED) was calculated using a water balance approach. The ED was calculated by subtracting the effects of evapotranspiration (ET), determined by the FAO Penman-Monteith method (Allen et al., 1998), and soil moisture deficits (SMD), using the Aslyng scale (Aslyng, 1965), from recorded rainfall amounts. The Aslyng scale adjusts ED to account for SMD $>30 \mathrm{~mm}$. Daily meteorological input parameters (rainfall, air temperature, and sunshine hours) were entered into the hybrid model for Irish grasslands developed by Schulte et al. (2005) to elucidate daily SMD, actual ET, and ED.

\section{Ceramic Cup Installation and Nitrate Measurement}

Ceramic suction cups (Van Walt Ltd., Haslemere, Surrey, UK) and sampling methods followed the same procedures as reported in detail in previous experiments (Ryan et al., 2006; Hooker et al., 2008; Premrov et al., 2012). Briefly, the porous suction cups with tubing attached were inserted into the soil, each having a bentonite seal at $1 \mathrm{~m}$ of depth. A total of 144 ceramic cups, 48 per treatment, were installed during autumn 2010 across 3 blocks in each farmlet (equivalent to $18 \%$ of the total farmlet area). The ceramic cups were installed 
with 16 cups per paddock in a grid type arrangement. Soil solution was sampled by applying suction (50 $\mathrm{kPa}$ ) to the cups using a hand-held pump $1 \mathrm{~d}$ before sample collection. Each of the 16 individual cups were sampled and then bulked into a single container for each paddock within each farmlet. Sampling took place every second week during the drainage period (from September to April) and once per month during the summer (May to August). On collection, the samples were stored in a cold box at $4^{\circ} \mathrm{C}$ and transported to the laboratory. The samples were stored in a freezer $\left(<-14^{\circ} \mathrm{C}\right)$ until analysis was undertaken. The samples were calorimetrically analyzed for total oxidizable $\mathrm{N}$, $\mathrm{NO}_{2}{ }^{-} \mathrm{N}, \mathrm{NH}_{4}{ }^{+} \mathrm{N}$, and total $\mathrm{N}(\mathbf{T N})$ using the Aquakem 600 Discrete analyzer (Aquakem 600A, 01621 Vantaa, Finland). Nitrate-N was determined by subtracting $\mathrm{NO}_{2}{ }^{-} \mathrm{N}$ from total oxidizable $\mathrm{N}$, which showed that $99.3 \%$ of total oxidizable $\mathrm{N}$ was $\mathrm{NO}_{3}{ }^{-} \mathrm{N}$. Ammonium-N concentrations were below the method detection limit (Premrov et al., 2012). Finally, total annual N losses ( $\mathrm{kg}$ of $\mathrm{N} /$ ha per year) were calculated as the product of effective rainfall and $\mathrm{N}$ concentration in the respective samples during each month.

\section{Statistical Analysis}

For all analyses undertaken, the individual paddock was considered to be the experimental unit. The effect of SR, block, year, and the interaction of SR and year on herbage utilization and chemical composition was determined using mixed models in SAS (Proc Mixed; SAS Institute, 2006); rotation was the repeated measure, and block and the interaction between SR and block were included as a random effect in the model. A compound symmetry covariance structure among records within paddock provided the best fit to the data. Tukey's test was used to determine differences between treatment means. Concentrate and silage supplementation per hectare and $\mathrm{N}$ fertilizer use per hectare were analyzed by variance analysis in SAS with the effect of year, block, SR, and their interactions included in the model.

\section{Modeling N Surplus and N Use Efficiency}

Due to the complexity and number of interactions within grazing systems, the efficiency of $\mathrm{N}$ use was modeled to further understand the processes underpinning each farm system treatment within each year of the current study using the $\mathrm{N}$ balance model described by Ryan et al. (2011). The model quantifies the movement of $\mathrm{N}$ among the various reservoirs possible in a grass-based system. The annual farm gate $\mathrm{N}$ surplus is the sum of annual $\mathrm{N}$ inputs less $\mathrm{N}$ outputs in the form of agricultural products. The $\mathrm{N}$ outputs from the farm system describe the $\mathrm{N}$ leaving the system in products (milk, meat, exported feedstuffs, and exported manure). Nitrogen in milk and $\mathrm{N}$ exported in livestock leaving the farm was calculated based on methods described by ARC (1994). Cows entering the farm system as replacements were estimated to have a mean BW 20\% less than that of the lactating cows to simulate a younger cow replacing an older cow. Slurry produced during the housed period was calculated as total $\mathrm{N}$ input consumed by the housed animals less $\mathrm{N}$ output ( $\mathrm{N}$ in milk and BW; Watson and Atkinson, 1999). As is typical of farming practices in Ireland, the replacement heifers were reared as a separate enterprise to milk production on the farm (usually on an outside block of land away from the milking cow grazing area).

\section{RESULTS}

\section{Climatic Data}

Average daily rainfall was greatest $(P<0.05)$ in November and December $(3.7 \pm 0.17$ and $3.9 \pm 0.16$ $\mathrm{mm} / \mathrm{d}$, respectively; means $\pm \mathrm{SEM}$ ) and least in March $(1.4 \pm 0.17 \mathrm{~mm} / \mathrm{d})$. Average total annual rainfall for the duration of the study was $996( \pm 52.2) \mathrm{mm}$. Due to the free-draining soil and location of the site on a karst limestone plateau, runoff was deemed to be negligible. Table 1 shows the mean monthly rainfall and ED for both the experimental period (2011 to 2013) and the 30 -yr average (1980 to 2010). Monthly average rainfall and ED from the 2011 to 2013 period was $81.0( \pm 7.53)$ and $35.4( \pm 5.38) \mathrm{mm}$, respectively, and were similar to the 30-yr averages $(85.0 \pm 8.14$ and $45.4 \pm 6.75 \mathrm{~mm}$, respectively). Over the $3 \mathrm{yr}$ of the study, the greatest $(P<0.01)$ maximum daily temperatures were recorded in July $\left(19.6 \pm 0.01^{\circ} \mathrm{C}\right)$, whereas the lowest $(P<0.001)$ average minimum daily temperature occurred in March $\left(2.2 \pm 0.12^{\circ} \mathrm{C}\right)$. Solar radiation was greatest $(P<0.05)$ during summer $\left(1,513 \pm 8.7 \mathrm{~J} / \mathrm{cm}^{2}\right.$ per day $)$ and least in winter $\left(163 \pm 11.0 \mathrm{~J} / \mathrm{cm}^{2}\right.$ per day). Mean ED (calculated as daily rainfall less ET) was greatest $(P<0.01)$ in November $(2.8 \pm 0.12 \mathrm{~mm} / \mathrm{d})$ and least $(P<0.01)$ in September $(0.1 \pm 0.04 \mathrm{~mm} / \mathrm{d})$.

\section{Grazing System Characteristics, Milk Production, Herbage Utilization, and Herbage $N$ Content}

Concentrate and fertilizer $\mathrm{N}$ inputs were similar for each SR treatment $(1,068 \mathrm{~kg}$ of concentrate $\mathrm{DM} /$ ha per year and $209 \mathrm{~kg}$ of $\mathrm{N} /$ ha per year, respectively). The total lactation milk production performance of animals in each SR has been reported previously (McCarthy et al., 2013b); thus, only the main effects of SR in each 
Table 1. Monthly total rainfall $[\mathrm{mm}(\mathrm{SD})]$ and drainage $[\mathrm{mm}(\mathrm{SD})]$ at the experimental site during the experimental period (2011 to 2013) compared with the 30-yr (1981 to 2010) average

\begin{tabular}{|c|c|c|c|c|}
\hline \multirow[b]{2}{*}{ Month } & \multicolumn{2}{|c|}{ Rainfall (mm) } & \multicolumn{2}{|c|}{ Drainage $(\mathrm{mm})$} \\
\hline & 30 -yr average & 2011-2013 & 30 -yr average & 2011-2013 \\
\hline January & $109(47)$ & $109(33)$ & $88(46)$ & $89(29)$ \\
\hline February & $80(48)$ & $61(31)$ & $58(45)$ & 38 (17) \\
\hline March & $85(34)$ & $79(35)$ & $51(30)$ & $39(26)$ \\
\hline April & $66(30)$ & $61(26)$ & $26(23)$ & $18(14)$ \\
\hline May & $69(39)$ & $78(11)$ & $17(25)$ & $19(9)$ \\
\hline June & $70(34)$ & $75(97)$ & $14(19)$ & $10(67)$ \\
\hline July & $64(39)$ & $86(18)$ & $9(17)$ & $19(14)$ \\
\hline August & $84(56)$ & $69(80)$ & $26(41)$ & $23(59)$ \\
\hline September & $77(48)$ & $74(40)$ & $25(29)$ & $13(5)$ \\
\hline October & $112(48)$ & $108(35)$ & $70(45)$ & $62(17)$ \\
\hline November & $104(56)$ & $115(53)$ & $79(57)$ & $89(46)$ \\
\hline December & $102(41)$ & $81(47)$ & $82(39)$ & $59(41)$ \\
\hline
\end{tabular}

year of the study are summarized in Table 2. The LSR treatment achieved the greatest milk production per cow in each year whereas HSR was least. Notwithstanding the lower individual animal performance, HSR achieved the greatest milk production per hectare, as a consequence of the increase in SR, whereas LSR was least. There was no significant SR effect on milk fat and protein content (46.6 and $37.3 \mathrm{~g} / \mathrm{kg}$, respectively). Grazing days per hectare were greatest for HSR (886 d), intermediate for MSR (797 d), and least for LSR (699 d). Grazing season length was unaffected by SR treatment and was, on average, $277 \mathrm{~d}$ per year during the experiment.

There was no significant year or year $\times$ SR treatment interaction effects on grazing characteristics, herbage use, and herbage $\mathrm{N}$ content observed; consequently, only the main effects of SR are detailed in Table 3. No difference was observed in net herbage accumulation $(14,637$ $\pm 329 \mathrm{~kg}$ of $\mathrm{DM} /$ ha per year), concentrate supplementation $(1,068 \pm 452 \mathrm{~kg}$ of $\mathrm{DM} / \mathrm{ha}$ per year), or the amount of $\mathrm{N}$ fertilizer applied to the grazing area (209 $\pm 46 \mathrm{~kg}$ of N/ha per year) between SR. However, there were differences in net herbage accumulation $(14,879$ $\pm 325,15,869 \pm 328$, and $13,164 \pm 326 \mathrm{~kg}$ of DM/ha in 2011, 2012, and 2013, respectively) and concentrate supplementation $(1,007 \pm 420,949 \pm 382$, and 1,249 \pm $463 \mathrm{~kg}$ of DM/ha in 2011, 2012, and 2013, respectively) between years. Stocking rate had a significant effect on all grazing variables, with the exception of pregrazing herbage mass $(1,690 \pm 57.0 \mathrm{~kg}$ of DM/ha) and herbage $\mathrm{N}$ content $(33.6 \pm 0.59 \mathrm{~g}$ of $\mathrm{N} / \mathrm{kg}$ of DM). Daily herbage allowance, postgrazing residual mass, and postgrazing residual sward height were greatest for LSR and least for HSR $(P<0.001)$. Average herbage removed per rotation was greater for MSR and HSR (1,698 \pm 53.3 and $1,643 \pm 57.8 \mathrm{~kg}$ of $\mathrm{DM} /$ ha, respectively) compared with LSR $(1,503 \pm 49.4 \mathrm{~kg}$ of DM/ha). Grazing efficiency at each grazing event was greatest $(P<0.01)$ for the HSR $(107 \pm 2.1 \%)$ and least $(P<0.05)$ for LSR $(95 \pm$ $2.2 \%)$, whereas MSR was intermediate $(102 \pm 2.1 \%)$. Conversely, average daily grazing area allowance per cow was greatest $(P<0.001)$ for $\operatorname{LSR}\left(108.4 \pm 2.5 \mathrm{~m}^{2}\right)$, least $(P<0.001)$ for HSR $\left(90.6 \pm 2.6 \mathrm{~m}^{2}\right)$, whereas MSR was intermediate $\left(100.2 \pm 2.6 \mathrm{~m}^{2}\right)$.

\section{Trends in Soil Solution Concentrations and Losses of $\mathrm{NO}_{3}{ }^{-} \mathrm{N}, \mathrm{NH}_{4}{ }^{-} \mathrm{N}$, and $\mathrm{NO}_{2}{ }^{-} \mathrm{N}$}

Soil solution concentrations of $\mathrm{NO}_{3}{ }^{-} \mathrm{N}, \mathrm{NH}_{4}{ }^{-} \mathrm{N}$, and $\mathrm{NO}_{2}{ }^{-} \mathrm{N}$ exhibited significant variation during the $3-\mathrm{yr}$ study period (Figure 1). Total $\mathrm{N}, \mathrm{NO}_{2}{ }^{-} \mathrm{N}$, and $\mathrm{NO}_{3}{ }^{-} \mathrm{N}$ concentrations were greatest $(P<0.01)$ in yr $1(41.6$ $\pm 7.0,0.5 \pm 0.07$, and $31.2 \pm 4.1 \mathrm{mg} / \mathrm{L}$, respectively), lowest $(P<0.01)$ in yr $2(26.5 \pm 7.0,0.3 \pm 0.08$, and $16.4 \pm 4.1 \mathrm{mg} / \mathrm{L}$, respectively), and intermediate during yr $3(33.8 \pm 7.0,0.4 \pm 0.08$, and $24.2 \pm 4.1 \mathrm{mg} / \mathrm{L}$, respectively). The greatest concentration levels of $\mathrm{NO}_{2}{ }^{-} \mathrm{N}$ and $\mathrm{NH}_{4}^{-} \mathrm{N}$ were recorded during midsummer, whereas $\mathrm{NO}_{3}{ }^{-} \mathrm{N}$ concentrations were high during both the summer and autumn periods in each year. Across all treatments and years, $\mathrm{NO}_{3}{ }^{-} \mathrm{N}$ losses explained $80 \%$ of TN loss, with a further $9 \%$ lost as $\mathrm{NH}_{4}{ }^{-} \mathrm{N}$. Stocking rate treatment had no significant effect on soil solution concentrations (Table 4 and Figure 1) or TN loss (Table 5), although a significant interaction was noted between SR treatment and year for all soil solution concentrations due to the comparably higher concentrations of all treatments in yr 1 in contrast to subsequent year. Effective drainage only occurred when rainfall exceeded ET and consequently climatic conditions had a large effect on actual $\mathrm{N}$ loss during the study period. Total annual $\mathrm{N}$ loss was similar during the study (at $136 \pm$ $15.3,139 \pm 12.6$, and $131 \pm 12.0 \mathrm{~kg}$ of $\mathrm{N} /$ ha during $\mathrm{yr}$ 1,2 , and 3 , respectively). 


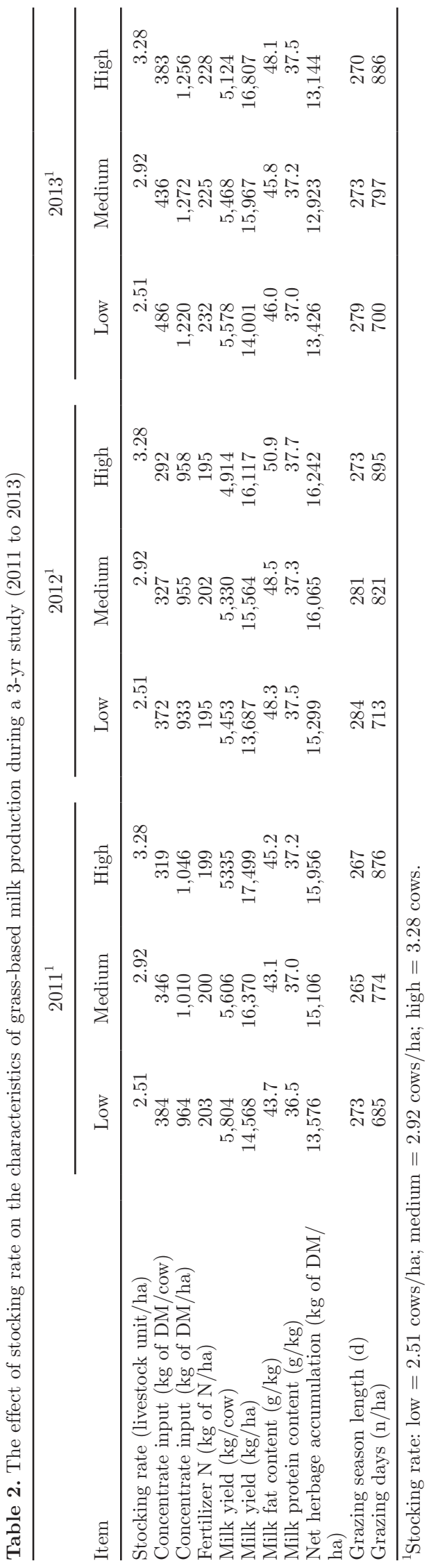

\section{N inputs, Outputs, and Utilization Efficiency}

The overall biological efficiency of $\mathrm{N}$ use for each treatment during each year of the study was modeled using the $\mathrm{N}$ efficiency model developed by Ryan et al. (2011) and based on the biological performance of each farming system, which is summarized in Table 2. The modeled effect of SR on annual farm gate $\mathrm{N}$ inputs, outputs, and surplus is presented in Table 6 . The main sources of $\mathrm{N}$ input to the dairy production systems were feed, $\mathrm{N}$ fertilizer, and replacement animals. Although the maximum permitted quantity of chemical fertilizer $\mathrm{N}$ allocated for each treatment was set at $250 \mathrm{~kg}$ of N/ ha per year, actual $\mathrm{N}$ applied across the 3 treatments for the 3-yr trial was $209 \mathrm{~kg}$ of N/ha. As concentrate input per hectare was similar for each SR treatment within year but varied between year due to variation in grass growth and climatic conditions, the quantity of $\mathrm{N}$ imported in feed was similar for each treatment but varied between years. As replacement rate and individual herd parity structure was maintained at a constant level for each SR treatment during the experimental period, the quantity of $\mathrm{N}$ imported as replacement animals was similar for each SR treatment. Total $\mathrm{N}$ input per hectare, consequently, was similar for each SR treatment in each year and averaged 225, 218, and $261 \mathrm{~kg}$ of N/ha for 2011, 2012, and 2013, respectively. The average quantity of $\mathrm{N}$ exported per hectare annually in the form of product was 116, 111, and $98 \mathrm{~kg}$ of $\mathrm{N} /$ ha for the HSR, MSR, and LSR, respectively, over the 3-yr period. Milk production was the main source of exported $\mathrm{N}$ from all dairy production systems, at 109,102 , and $90 \mathrm{~kg}$ of $\mathrm{N} /$ ha per year for HSR, MSR, and LSR, respectively (Table 6). The quantity of $\mathrm{N}$ exported in the form of calf sales was 4,3 , and $3 \mathrm{~kg}$ of $\mathrm{N} /$ ha per year for the HSR, MSR, and LSR, respectively, whereas cull cow sales was 9,8 , and $7 \mathrm{~kg}$ of $\mathrm{N} /$ ha per year, respectively. The average annual farm-gate $\mathrm{N}$ surplus per hectare ( $\mathrm{N}$ inputs less $\mathrm{N}$ outputs) differed with SR and was 136, 124, and $121 \mathrm{~kg}$ of $\mathrm{N} /$ ha per year for LSR, MSR, and HSR, respectively. Similarly, mean $\mathrm{N}$ use efficiency ( $\mathrm{N}$ outputs/N inputs) for all systems was $46 \%$, and was highest for HSR (49\%), lowest for LSR (42\%), and intermediate for MSR (47\%).

\section{DISCUSSION}

Within an EU context, Ireland currently has excellent water quality, with $86 \%$ of groundwater aquifers classified at good status or better (EPA, 2010). Maintaining the delicate balance between productive agriculture and groundwater quality is a constant challenge and requires a broad overall farm systems perspective over different time and dimensional scales, and recent 
Table 3. Effect of stocking rate ${ }^{1}$ (SR) on grazing characteristics and utilization over 3 grazing seasons (2011 to 2013)

\begin{tabular}{|c|c|c|c|c|c|}
\hline Item & Low & Medium & High & SEM & $P$-value \\
\hline Pregrazing mass (kg of DM/ha) & 1,677 & 1,763 & 1,631 & 57.0 & 0.3 \\
\hline Postgrazing mass (kg of DM/ha) & $174^{\mathrm{a}}$ & $65^{\mathrm{b}}$ & $-12^{\mathrm{c}}$ & 27.2 & $* * *$ \\
\hline Postgrazing height $(\mathrm{cm})$ & $4.0^{\mathrm{a}}$ & $3.7^{\mathrm{ab}}$ & $3.4^{\mathrm{b}}$ & 0.09 & $* * *$ \\
\hline Herbage allowance ( $\mathrm{kg}$ of $\mathrm{DM} /$ cow per day) & $16.5^{\mathrm{a}}$ & $15.5^{\mathrm{b}}$ & $13.1^{\mathrm{c}}$ & 0.43 & $* * *$ \\
\hline${\text { Herbage } \text { used }^{2}(\mathrm{~kg} \text { of DM} / \mathrm{ha})}$ & $1,503^{\mathrm{b}}$ & $1,698^{\mathrm{a}}$ & $1,643^{\mathrm{a}}$ & 53.5 & * \\
\hline Grazing efficiency $^{3}(\%)$ & $95^{\mathrm{c}}$ & $102^{\mathrm{b}}$ & $107^{\mathrm{a}}$ & 2.1 & $* *$ \\
\hline Grazing area allocation $\left(\mathrm{m}^{2} / \mathrm{cow}\right.$ per day) & $108.4^{\mathrm{a}}$ & $100.2^{\mathrm{b}}$ & $90.6^{\mathrm{c}}$ & 2.56 & *** \\
\hline Herbage $\mathrm{N}$ content $(\mathrm{g} / \mathrm{kg})$ & 33.0 & 33.8 & 33.9 & 0.59 & 0.4 \\
\hline
\end{tabular}

${ }^{\mathrm{a}-c}$ Means within a row with different superscripts differ.

${ }^{1}$ Stocking rate: Low $=2.51$ cows $/$ ha, Medium $=2.92 \mathrm{cows} /$ ha, High $=3.28$ cows $/$ ha

${ }^{2}$ Herbage used $(\mathrm{kg}$ of DM/ha) $=$ (pregrazing sward height - postgrazing sward height $) \times$ sward density $(\mathrm{kg}$ of $\mathrm{DM} / \mathrm{cm}$ per ha; Delaby and Peyraud, 1998).

${ }^{3}$ Grazing efficiency $(\%)=($ Herbage used/Pregrazing herbage mass $) \times 100$.

${ }^{*} P<0.05,{ }^{* *} P<0.01,{ }^{* * *} P<0.001$.

studies have highlighted the necessity for estimates of nutrient efficiency to be integrated within technical efficiency evaluation criteria for productive farming systems (Shani et al., 2007; Dudley et al., 2008). The range of SR treatments evaluated within the current experiment are relatively intensive in comparison with commercial practice in Ireland $[1.9$ livestock units (dairy cow equivalents)/ha; NFS, 2012]. However, these high-SR farms must be considered in terms of the comparably high productivity of the grassland swards at the experimental site. The LSR treatment represents the control SR, whereas MSR and HSR represent 2 incremental increases in SR.

Previous studies evaluating the efficacy of increased farm system SR within grazing systems have conclusively illustrated beneficial effects on per-hectare milk production (Hoden et al., 1991; Macdonald et al., 2008; McCarthy et al., 2013b), pasture quality and utilization (Horan et al., 2005; Macdonald et al., 2008; McCarthy et al., 2013a), and overall farm system economic performance (Shalloo et al., 2004; McCarthy et al., 2007; McDonald et al., 2013). The biological effects of increased overall farm SR on milk production per hectare observed within our study are consistent with previous findings and further substantiate the potential for increased biological efficiency within higherSR grazing systems. Similar to both Valentine et al. (2009) and Fariña et al. (2011), SR had no significant effect on net herbage accumulation but, as a consequence of the increased efficiency of herbage removal and increased grazing severity at higher SR, resulted in increased grazed grass utilization. Both Baudracco et al. (2010) and McCarthy et al. (2011) have previously likened an increase in SR to a reduction in daily herbage allowance. In the current study, increasing SR resulted in reduced daily herbage allowance, reduced total lactation milk production per cow, and increased milk production per hectare, which is consistent with previous experiments at similar SR (Macdonald et al., 2008; Fariña et al., 2011). Unlike Fariña et al. (2011), who attributed much of the increase in milk production per hectare at higher SR to increased supplementation, the increased milk production per hectare achieved at higher SR in the present study is directly related to an increase in grazed herbage as supplementary feed imports were similar for each SR treatment $(1,060 \mathrm{~kg} /$ ha per year). The overall level of milk production per hectare achieved within our study greatly exceeds that obtained commercially on Irish dairy farms $(9,120 \mathrm{~kg}$ of milk/ha per year; NFS, 2012), and is indicative of the potential productivity of Irish grass-based systems post-milk quota in the EU.

The efficacy of ceramic cup evaluations of $\mathrm{N}$ losses from freely draining soils has been validated by Webster et al. (1993) and has been reported previously within intensive grazing systems (Ryan et al., 2006). The overall quantity of $\mathrm{NO}_{3}{ }^{-} \mathrm{N}$ and $\mathrm{TN}$ leached from the farm system is dependent on the volume of water drained from the soil and the concentration of $\mathrm{NO}_{3}{ }^{-} \mathrm{N}$ in the drainage water (Cooper et al., 2007; Huebsch et al., 2013). The average rainfall and ED during the study were similar to the 30-yr average, and so the observed results are consistent with normal expected weather and drainage conditions for this site. Total $\mathrm{N}, \mathrm{NO}_{2}{ }^{-} \mathrm{N}$, $\mathrm{NH}_{4}{ }^{-} \mathrm{N}$, and $\mathrm{NO}_{3}{ }^{-} \mathrm{N}$ concentrations reported in our study $(32.3,0.2,2.4$, and $26.0 \mathrm{mg} / \mathrm{L}$, respectively) were similar to the concentrations in soil solution reported previously by Ryan et al. (2006), whereas the large inherent variation in mean $\mathrm{NO}_{3}{ }^{-} \mathrm{N}$ and $\mathrm{TN}$ concentrations in soil solution both within and between year (Figure 1) has also previously been reported (Richards et al., 1996; Sprosen et al., 2002). Total N losses were similar to those measured in dairy systems on similar soils in New Zealand using ceramic cups after the application 
a)

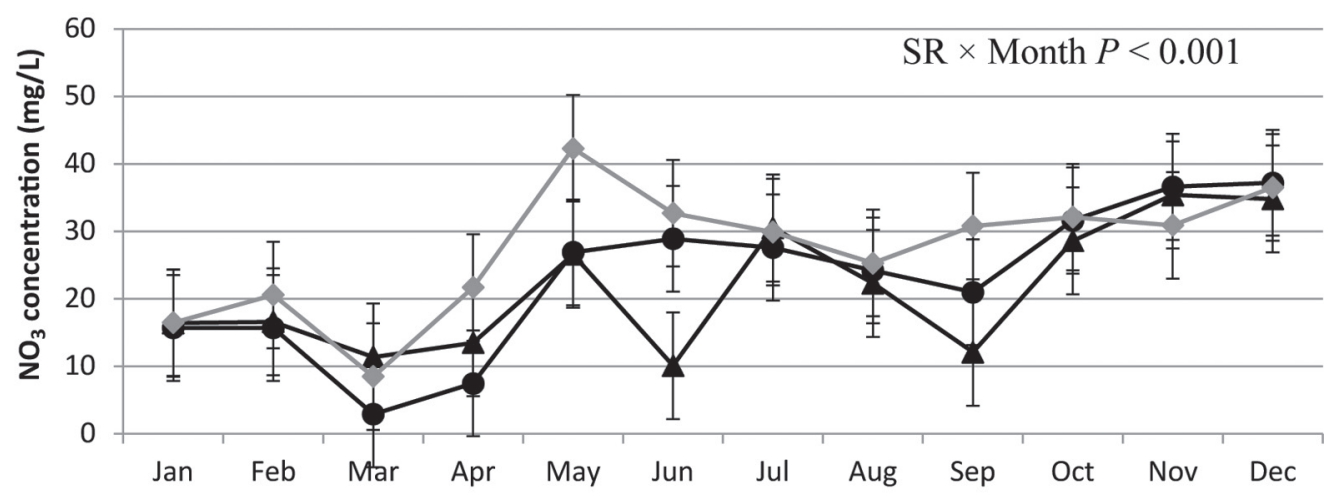

b)

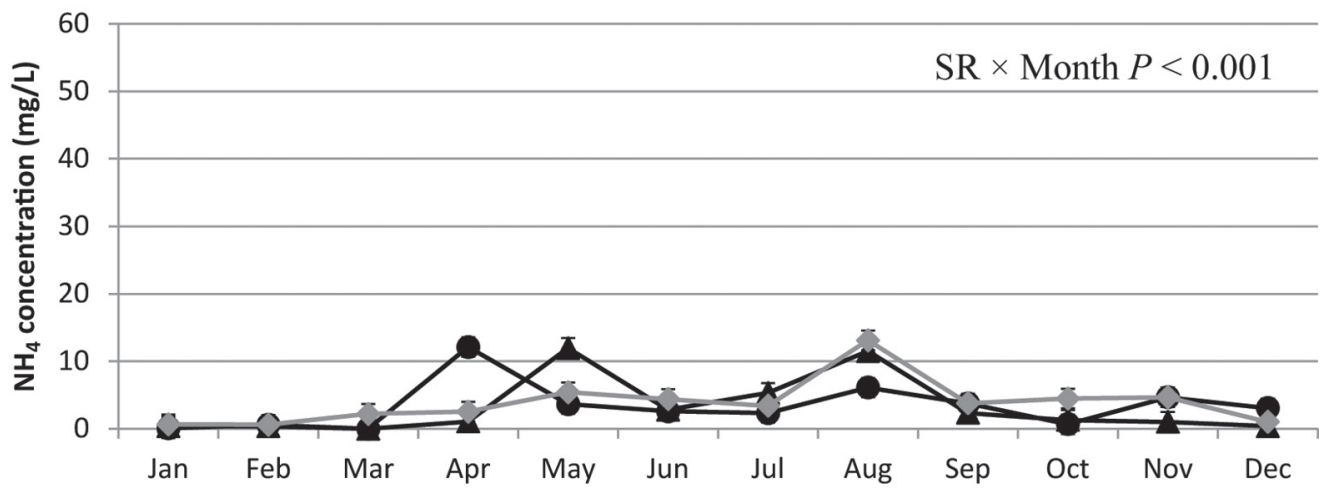

c)

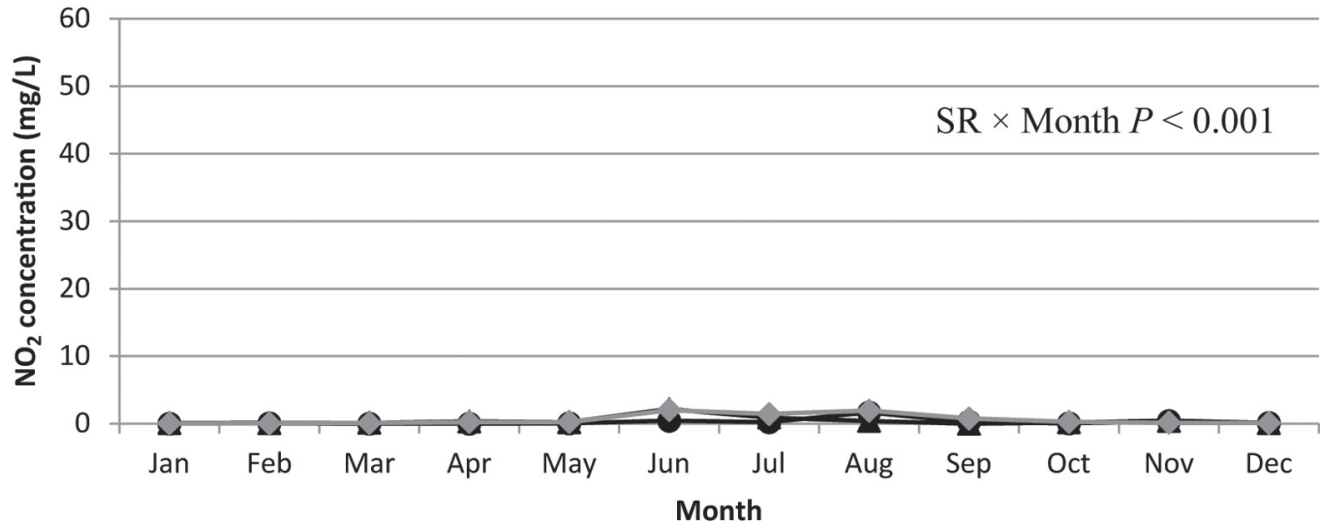

Figure 1. The effect of stocking rate (SR) on mean average monthly soil solution concentrations of (a) nitrate- $\mathrm{N}\left(\mathrm{NO}_{3}-\mathrm{N}\right)$, (b) ammonium$\mathrm{N}\left(\mathrm{NH}_{4}-\mathrm{N}\right)$, and $(\mathrm{c})$ nitrite- $\mathrm{N}\left(\mathrm{NO}_{2}-\mathrm{N}\right)$ for the low $(2.51 \mathrm{cows} / \mathrm{ha} ; \boldsymbol{\Delta})$, medium (2.92 cows/ha; $\left.\bullet\right)$, and high $(3.28$ cows/ha; $)$ SR treatments during the 3 -yr study period.

of $200 \mathrm{~kg}$ of $\mathrm{N} /$ ha as mineral fertilizer $\left(\mathrm{NO}_{3}{ }^{-} \mathrm{N}\right.$ leaching losses of $101 \mathrm{~kg}$ of $\mathrm{N} /$ ha per year; Ledgard et al., 1997). Although $\mathrm{NO}_{3}{ }^{-} \mathrm{N}$ concentrations in soil solution (26.0 mg of $\mathrm{NO}_{3}{ }^{-} \mathrm{N} / \mathrm{L}$ ) consistently exceeded the current EU standard for $\mathrm{NO}_{3}{ }^{-} \mathrm{N}$ in drinking water $(11.3 \mathrm{mg} / \mathrm{L})$ for all SR treatments, previous studies have indicated that soil solution concentrations of $\mathrm{NO}_{3}{ }^{-} \mathrm{N}$ are likely to be a poor reflection of absolute losses to groundwater (Ryan et al., 2006). Huebsch et al. (2013) has reported mean $\mathrm{NO}_{3}{ }^{-} \mathrm{N}$ concentrations of $7.0 \mathrm{mg} / \mathrm{L}$ in groundwater beneath the experimental site during the same measurement period. The same study (Huebsch et al., 2013), which evaluated groundwater $\mathrm{NO}_{3}{ }^{-} \mathrm{N}$ concentrations over an 11-yr period, also observed no significant effect 
Table 4. Effect of stocking rate ${ }^{1}(\mathrm{SR})$ on annual total $\mathrm{N}(\mathrm{TN})$, nitrate $\mathrm{N}\left(\mathrm{NO}_{3}-\mathrm{N}\right)$, nitrite $\mathrm{N}\left(\mathrm{NO}_{2}-\mathrm{N}\right)$, and ammonium $\mathrm{N}\left(\mathrm{NH}_{4}-\mathrm{N}\right)$ concentrations $(\mathrm{mg} / \mathrm{L})$ over 3 grazing seasons (2011 to 2013)

\begin{tabular}{|c|c|c|c|c|c|c|c|}
\hline \multirow[b]{2}{*}{ Item } & \multicolumn{3}{|c|}{ SR } & \multirow[b]{2}{*}{ SEM } & \multicolumn{3}{|c|}{$P$-value } \\
\hline & Low & Medium & High & & $\mathrm{SR}$ & Year & $\mathrm{SR} \times$ year \\
\hline \multicolumn{8}{|c|}{ TN concentration $(\mathrm{mg} / \mathrm{L})$} \\
\hline Average & 35.4 & 36.1 & 30.4 & 12.1 & 0.9 & $* * *$ & $* * *$ \\
\hline 2011 & 44.1 & 44.4 & 36.2 & & & & \\
\hline 2012 & 31.1 & 28.7 & 19.8 & & & & \\
\hline 2013 & 31.1 & 35.2 & 35.1 & & & & \\
\hline \multicolumn{8}{|c|}{$\mathrm{NO}_{3}-\mathrm{N}$ concentration $(\mathrm{mg} / \mathrm{L})$} \\
\hline Average & 21.5 & 27.3 & 23.0 & 7.06 & 0.9 & $* * *$ & $* * *$ \\
\hline 2011 & 29.1 & 34.9 & 29.5 & & & & \\
\hline 2012 & 17.4 & 19.0 & 12.9 & & & & \\
\hline 2013 & 18.1 & 28.1 & 26.6 & & & & \\
\hline \multicolumn{8}{|c|}{$\mathrm{NO}_{2}-\mathrm{N}$ concentration $(\mathrm{mg} / \mathrm{L})$} \\
\hline Average & 0.4 & 0.6 & 0.2 & 0.13 & 0.2 & $* *$ & $* * *$ \\
\hline 2011 & 0.6 & 0.6 & 0.2 & & & & \\
\hline 2012 & 0.3 & 0.6 & 0.2 & & & & \\
\hline 2013 & 0.3 & 0.6 & 0.4 & & & & \\
\hline \multicolumn{8}{|c|}{$\mathrm{NH}_{4}-\mathrm{N}$ concentration $(\mathrm{mg} / \mathrm{L})$} \\
\hline Average & 5.2 & 4.5 & 2.1 & 0.93 & 0.4 & $* * *$ & $* * *$ \\
\hline 2011 & 4.1 & 4.5 & 2.0 & & & & \\
\hline 2012 & 4.1 & 3.3 & 2.0 & & & & \\
\hline 2013 & 5.6 & 3.7 & 5.3 & & & & \\
\hline
\end{tabular}

${ }^{1}$ Stocking rate: low $=2.51$ cows $/$ ha; medium $=2.92 \mathrm{cows} /$ ha; high $=3.28 \mathrm{cows} /$ ha.

** $P<0.01,{ }^{* * *} P<0.001$.

of SR on $\mathrm{N}$ loss and concluded that intensive grassbased systems of production incorporating efficient $\mathrm{N}$ management practices can lead to an achievement of the water quality targets. The large disparity in $\mathrm{N}$ loss estimates between soil solution and groundwater concentrations evidenced by these results suggest that further research is needed to understand the complex dynamics of $\mathrm{N}$ transformations and movement from surface to groundwater.

In the current study, the evaluation of SR effects under grazing occurs under a common level of drainage; thus, the effect of $\mathrm{SR}$ on $\mathrm{NO}_{3}^{-} \mathrm{N}$ leaching is considered

Table 5. Effect of stocking rate ${ }^{1}(\mathrm{SR})$ on annual total nitrogen $\mathrm{N}(\mathrm{TN})$, nitrate $\mathrm{N}\left(\mathrm{NO}_{3}-\mathrm{N}\right)$, nitrite $\mathrm{N}\left(\mathrm{NO}_{2}-\mathrm{N}\right)$, and ammonium $\mathrm{N}\left(\mathrm{NH}_{4}-\mathrm{N}\right)$ loss ( $\mathrm{kg} \mathrm{N} /$ ha) over 3 grazing seasons (2011 to 2013)

\begin{tabular}{|c|c|c|c|c|c|c|c|}
\hline \multirow[b]{2}{*}{ Item } & \multicolumn{3}{|c|}{ SR } & \multirow[b]{2}{*}{ SEM } & \multicolumn{3}{|c|}{$P$-value } \\
\hline & Low & Medium & High & & SR & Year & $\mathrm{SR} \times$ year \\
\hline \multicolumn{8}{|c|}{$\mathrm{TN}$ loss $(\mathrm{kg} / \mathrm{ha}$ per year $)$} \\
\hline Average & 127.8 & 136.6 & 141.2 & 15.10 & 0.8 & 0.9 & 0.3 \\
\hline 2011 & 129.2 & 136.8 & 142.2 & & & & \\
\hline 2012 & 144.1 & 152.9 & 119.9 & & & & \\
\hline 2013 & 110.1 & 120.0 & 161.5 & & & & \\
\hline \multicolumn{8}{|c|}{$\mathrm{NO}_{3}-\mathrm{N}$ loss $(\mathrm{kg} /$ ha per year) } \\
\hline Average & 99.9 & 109.6 & 113.1 & 15.22 & 0.7 & $\dagger$ & 0.6 \\
\hline 2011 & 113.1 & 118.4 & 123.2 & & & & \\
\hline 2012 & 88.6 & 102.2 & 86.9 & & & & \\
\hline 2013 & 97.9 & 108.2 & 129.1 & & & & \\
\hline \multicolumn{8}{|c|}{$\mathrm{NO}_{2}-\mathrm{N}$ loss $(\mathrm{kg} /$ ha per year) } \\
\hline Average & 1.1 & 1.8 & 1.1 & 0.64 & 0.7 & $* *$ & $\dagger$ \\
\hline 2011 & 1.5 & 0.3 & 0.2 & & & & \\
\hline 2012 & 1.5 & 4.8 & 2.1 & & & & \\
\hline 2013 & 0.2 & 0.3 & 0.9 & & & & \\
\hline \multicolumn{8}{|c|}{$\mathrm{NH}_{4}-\mathrm{N}$ loss (kg/ha per year) } \\
\hline Average & 10.2 & 13.3 & 12.8 & 4.69 & 0.9 & $\dagger$ & $\dagger$ \\
\hline 2011 & 3.3 & 11.7 & 5.8 & & & & \\
\hline 2012 & 22.7 & 23.1 & 10.1 & & & & \\
\hline 2013 & 4.5 & 5.2 & 22.5 & & & & \\
\hline
\end{tabular}

${ }^{1}$ Stocking rate: low $=2.51$ cows $/$ ha; medium $=2.92$ cows $/$ ha; high $=3.28 \mathrm{cows} /$ ha.

$\dagger P<0.10,{ }^{* *} P<0.01$. 
Table 6. The modeled effect of stocking rate ${ }^{1}$ on annual farm gate nitrogen (N) inputs, outputs, and surplus during the 3-yr study (2011 to 2013)

\begin{tabular}{|c|c|c|c|c|c|c|c|c|c|}
\hline Item & \multicolumn{3}{|c|}{2011} & \multicolumn{3}{|c|}{2012} & \multicolumn{3}{|c|}{2013} \\
\hline \multicolumn{10}{|l|}{$\mathrm{N}$ input $(\mathrm{kg}$ of $\mathrm{N} / \mathrm{ha})$} \\
\hline Feed & 18 & 19 & 20 & 14 & 16 & 18 & 24 & 28 & 32 \\
\hline Annual replacement cows introduced & 5 & 5 & 6 & 4 & 5 & 6 & 5 & 5 & 6 \\
\hline Total & 226 & 224 & 225 & 213 & 223 & 219 & 261 & 258 & 266 \\
\hline Meat & 10 & 12 & 13 & 10 & 11 & 13 & 10 & 11 & 13 \\
\hline Total & 100 & 113 & 122 & 96 & 109 & 110 & 97 & 111 & 116 \\
\hline $\mathrm{N}$ surplus (kg of $\mathrm{N} / \mathrm{ha}$ ) & 126 & 111 & 103 & 117 & 114 & 109 & 164 & 147 & 150 \\
\hline $\mathrm{N}$ use efficiency & 0.44 & 0.50 & 0.54 & 0.45 & 0.49 & 0.50 & 0.37 & 0.43 & 0.44 \\
\hline
\end{tabular}

${ }^{1}$ Stocking rate: low $=2.51$ cows $/$ ha; medium $=2.92$ cows $/$ ha; high $=3.28$ cows.

in terms of N concentrations in soil solution. Similar to previous studies, the results of the current analysis indicate that although $\mathrm{NO}_{3}{ }^{-} \mathrm{N}$ and $\mathrm{TN}$ concentrations in soil solution are high during summer as little $\mathrm{N}$ loss occurs during the February to October period due to low rainfall and increased ET. The important effect of climatic conditions on $\mathrm{N}$ losses observed in previous studies (O'Connell et al., 2004; Kurunc et al., 2011) is also evident in the current data. Similar to both De Klein and Ledgard (2001) and Laidlaw and Mayne (2000), the combination of high $\mathrm{N}$ concentrations and increased ED during the autumn and early winter months within the current data are indicative of the increased risk of $\mathrm{N}$ loss during this period. Sprosen et al. (2002) have also previously reported no significant SR effect on $\mathrm{NO}_{3}{ }^{-} \mathrm{N}$ losses from grazing swards in New Zealand and concluded that this was due to the lower grass DMI and an earlier end to lactation and removal of cull cows in high-SR treatments. The results of the present study are in agreement with previous SR evaluation studies, both in Ireland (Ryan et al., 2006) and internationally (Sprosen et al., 2002; Monaghan et al., 2009), and indicate that within the range of production systems investigated and at similar $\mathrm{N}$ inputs, increasing $\mathrm{SR}$ has no effect on $\mathrm{N}$ losses from soil solution within a predominantly grass-based production system on a freedraining site. The significant interaction between SR treatment and year for all soil solution concentrations in the current study was due to the comparably higher concentrations of all treatments in yr 1 and indicates that such analysis must be undertaken over multiple years. Overall N inputs, outputs, and surpluses generated by the adoption of the production data to the $\mathrm{N}$ model of Ryan et al. (2011) are consistent with previous studies within grass-based systems (Ledgard et al., 1999). They indicated that the increased grass utilization and milk production per hectare at higher SR result in a reduction in $\mathrm{N}$ surplus and an increase in $\mathrm{N}$ use efficiency. In the absence of extra $\mathrm{N}$ inputs (chemical fertilizer and concentrates), which are traditionally associated with increased SR and which result in increased N loss (Humphreys et al., 2003), the results of the experiment reported herein highlight the possibility for the sustainable intensification of Irish dairy systems through a combination of increased SR, greater grazing intensity, and increased herbage utilization.

Many studies report increased farm system productivity at higher SR (McCarthy et al., 2011), with increased performance within such systems being attributed to a combination of improved pasture utilization and increased chemical $\mathrm{N}$ fertilizer application and increased feed supplementation (Valentine et al., 2009; Fariña et al., 2011). Whitehead (1995) concluded that additional $\mathrm{N}$ applications at higher SR reduce $\mathrm{N}$ utilization due to the inability of such systems to use additional $\mathrm{N}$ inputs above those required for herbage and animal production, whereas Ryan et al. (2011) concluded that $40 \%$ of the extra $\mathrm{N}$ input is lost to the environment. Consequently, it is now widely acknowledged that the magnitude of $\mathrm{N}$ inputs to the farm system is generally the main factor determining the $\mathrm{N}$ surplus and therefore the potential for $\mathrm{N}$ loss (Treacy et al., 2008; Monaghan et al., 2009; Ryan et al., 2012). Previous estimates of between 19 and $24 \% \mathrm{~N}$ use efficiency based on overall farm SR of 2 to 3 livestock units/ ha and N surpluses of 200 to $250 \mathrm{~kg}$ of N/ha per year have been reported for Irish dairy farms (Humphreys et al., 2008; Treacy et al., 2008; Mihailescu et al., 2014). Similarly, Ledgard et al. (1997) estimated the average New Zealand farm N use efficiency at $30 \%$ based on an $\mathrm{N}$ surplus of circa $130 \mathrm{~kg}$ of $\mathrm{N} / \mathrm{ha}$ per year. In comparison with the aforementioned commercial farm data and previous grazing studies in Ireland (Horan et al., 2005; Coleman et al., 2010), the comparatively reduced total $\mathrm{N}$ inputs (235 kg/ha per year) and $\mathrm{N}$ surplus $(127 \mathrm{~kg} /$ ha per year) from both chemical $\mathrm{N}$ and supplementary 
feeds and increased milk production per hectare in the current experiment resulted in increased mean $\mathrm{N}$ use efficiency (46\%), which is supported by the similarity in grass $\mathrm{N}$ content among $\mathrm{SR}$ treatments within our experiment. Furthermore, these results indicate that, as $\mathrm{SR}$ increased, further improvements in $\mathrm{N}$ surplus and $\mathrm{N}$ use efficiency are achieved at higher $\mathrm{SR}$ as $\mathrm{N}$ is recycled more efficiently within such systems. Peyraud and Delaby (2006) previously observed improvements in N use efficiency from both low $\mathrm{N}$ fertilization and increased $\mathrm{SR}$ and concluded that low $\mathrm{N}$ fertilizer input is critical to improve $\mathrm{N}$ use efficiency at high $\mathrm{SR}$ as $\mathrm{N}$ surplus is reduced to a greater extent than $\mathrm{N}$ exported in milk.

The efficiency of conversion of inputs to products is one of the main areas of improvement necessary in the search for more sustainable grass-based food production systems. The results reported in the current study provide an insight into the potential productivity and nutrient efficiency of technically focused grazing systems based on high-genetic potential dairy cattle and high-productivity grassland swards $(14,637 \mathrm{~kg}$ of $\mathrm{DM} /$ ha per year) with medium total $\mathrm{N}$ inputs $(235 \mathrm{~kg}$ of $\mathrm{N} /$ ha per year). In contrast, commercial farm data indicates that, based on increased $\mathrm{N}$ input, average grass DM production on intensive Irish dairy farms in Ireland is approximately $10,000 \mathrm{~kg}$ of $\mathrm{DM} /$ ha per year (Shalloo et al., 2010), resulting in reduced milk production per hectare (NFS, 2012), increased concentrate supplementation (Ramsbottom et al., 2012), and, ultimately, reduced $\mathrm{N}$ use efficiency (Treacy et al., 2008; Mihailescu et al., 2014). These differences indicate the potential contribution of improved basic agronomic and nutrient management practices at the farm level to increase grazed grass utilization, resulting in increased farm system productivity from highly $\mathrm{N}$ efficient grazing systems.

\section{CONCLUSIONS}

The results of this study indicate that $\mathrm{NO}_{3}{ }^{-} \mathrm{N}$ and TN concentrations in soil solution did not differ significantly between SR treatments [LSR (2.51 cows/ha), MSR (2.92 cows/ha), and HSR (3.28 cows/ha)] when N inputs from chemical $\mathrm{N}$ fertilizer or additional external feed supplementation were restricted and increased grazed grass utilization was used to support the feed requirements of animals at higher SR. The results highlight the possibility for the sustainable intensification of Irish grass-based systems of milk production through increased grazed grass utilization within high-productivity grazing systems. Moreover, the results suggest that, at the same level of $\mathrm{N}$ inputs, increasing SR has little effect on $\mathrm{N}$ loss in pastoral systems as described with limited imported feed, and that greater empha- sis should be attributed to increased grass production and utilization under grazing systems or conditions to further improve the environmental impact of grazing systems of production.

\section{ACKNOWLEDGMENTS}

We acknowledge the financial support of the Irish Dairy Levy and Teagasc Walsh Fellowship Scheme. Special thanks go to the staff of Curtins Research Farm (Teagasc, Animal \& Grassland Research and Innovation Centre, Moorepark, Fermoy, Co. Cork, Ireland) for their cooperation, care, and management of the experimental area. We also thank D. Brennan (Teagasc, Johnstown Castle, Co. Wexford, Ireland) and Laure Ronsin (Teagasc, Animal \& Grassland Research and Innovation Centre, Moorepark, Fermoy, Co. Cork, Ireland) for technical assistance over the course of the study.

\section{REFERENCES}

Allen, R. G., L. S. Pereira, D. Raes, and M. Smith. 1998. Crop evapotranspiration guidelines for computing crop water requirements. Page 227 in FAO Irrigation and Drainage Paper. Vol. 56. FAO, Rome, Italy.

ARC (Agricultural Research Council). 1994. The nutrient requirements of ruminant livestock. Page 351 in Technical Review by an Agricultural Research Council Working Party. CAB International, Oxon, UK.

Aslyng, H. C. 1965. Evaporation, evapotranspiration and water balance investigations at Copenhagen 1955-64. Acta Agric. Scand. 15:284-300.

Bartley, P., and P. Johnston. 2006. Eutrophication from Agriculture Sources. Nitrate Leaching-Groundwater (2000-L S 2.3.1.3). Final Report. EPA, Wexford, Ireland.

Baudracco, J., N. Lopez-villalobos, C. W. Holmes, and K. A. Macdonald. 2010. Effects of stocking rate, supplementation, genetic strain and their interactions on grazing dairy systems: A review. N. Z. J. Agric. Res. 53:109-133.

Coleman, J., K. M. Pierce, D. P. Berry, A. Brennan, and B. Horan. 2010. Increasing milk solids production across lactation through genetic selection and intensive pasture-based feed system. J. Dairy Sci. 93:4302-4317.

Cooper, R., V. Thoss, and H. Watson. 2007. Factors influencing the release of dissolved organic carbon and dissolved forms of nitrogen from a small upland headwater during autumn runoff events. Hydrol. Processes 21:622-633.

Department of Agriculture, Food and the Marine (DAFM). 2011. Food Harvest 2020. Department of Agriculture, Fisheries, and Food, Dublin, Ireland.

De Klein, C. A. M., and S. F. Ledgard. 2001. An analysis of environmental and economic implications of nil and restricted grazing systems designed to reduce nitrate leaching from New Zealand dairy farms. I. Nitrogen losses. N. Z. J. Agric. Res. 44:201-215.

Decau, M. L., L. Delaby, and B. Roche. 1997. AzoPât: Une description quantifiée des flux annuels d'azote en prairie pâturée par les vaches laitières (A quantitative description of the annual nitrogen flux in grassland grazed by dairy cows). 11-Les flux du système sol - plante (The flow of soil-plant system). Fourrages 151:313-330.

Delaby, L., and J. L. Peyraud. 1998. Effect d'une réduction simultanée de la fertilisation azotée et du chargement sur les performances des vaches laitières et la valorisation du pâturage (Effect of a simultaneous reduction in nitrogen fertilization and stocking rate 
on the performance of dairy cows and pasture utilization). Ann. Zootech. 47:17-39.

Di, H. J., and K. C. Cameron. 2002a. Nitrate leaching in temperate agroecosystems: Sources, factors and mitigating strategies. Nutr. Cycl. Agroecosyst. 46:237-256.

Di, H. J., and K. C. Cameron. 2002b. The use of a nitrification inhibitor, dicyandiamide (DCD), to decrease nitrate leaching and nitrous oxide emissions in simulated grazed and irrigated grassland. Soil Use Manage. 18:395-403.

Dillon, P., J. R. Roche, L. Shalloo, and B. Horan. 2005. Optimising financial return from grazing in temperate pastures. Pages 131147 in Utilisation of Grazed Grass in Temperate Animal Systems. Proceedings of a Satellite Workshop of the 20th International Grassland Congress, July 2005, Cork, Ireland. J. J. Murphy, ed. Wageningen Academic Publishers, Wageningen, the Netherlands.

Dudley, L. M., A. Ben-Gal, and N. Lazarovitch. 2008. Drainage water reuse: Biological, physical, and technological considerations for system management . J. Environ. Qual. 37:S25-35.

Environmental Protection Agency (EPA). 2010. Water Quality in Ireland 2007-2009. Accessed June 10, 2014. http://www.epa.ie/pubs/ reports/water/waterqua/.

FAO. 2014. Food and Agriculture Organization of the United Nations. Accessed Apr. 2014. http://www.fao.org/agriculture/crops/ thematic-sitemap/theme/spi/grasslands-rangelands-and-foragecrops/en/.

Fariña, S. R., S. C. Garcia, W. J. Fulkerson, and I. M. Barchia. 2011. Pasture-based dairy farm systems increasing milk production through stocking rate or milk yield per cow: Pasture and animal responses. Grass Forage Sci. 66:316-332.

Gibbons, P., M. Rodgers, and J. Mulqueen. 2006. Eutrophication from Agriculture Sources. Nitrate Leaching - Soil Investigation (2000LS - 2.3.1.2.). Final Report. EPA, Wexford, Ireland.

Gourley, C. J. P., S. R. Aarons, and J. M. Powell. 2012. Nitrogen use efficiency and manure management in contrasting dairy production systems. Agric. Ecosyst. Environ. 147:73-81.

Haynes, R. J., and P. H. Williams. 1993. Nutrient cycling and soil fertility in the grazed pasture ecosystem. Adv. Agron. 49:119-199.

Huebsch, M., B. Horan, P. Blum, K. G. Richards, J. Grant, and O. Fenton. 2013. Impact of agronomic practices of an intensive dairy farm on nitrogen concentrations in a karst aquifer in Ireland. $\mathrm{Ag}$ ric. Ecosyst. Environ. 179:187-199.

Hoden, A., J. L. Peyraud, A. Muller, L. Delaby, and P. Faverdin. 1991. Simplified rotational grazing management of dairy cows: Effects of rates of stocking and concentrate. J. Agric. Sci. 116:417-428.

Hooker, K. V., C. E. Coxon, R. Hackett, L. E. Kirwan, E. O'Keefe, and K. G. Richards. 2008. Evaluation of cover crop and reduced cultivation for reducing nitrate leaching in Ireland. J. Environ. Qual. 37:138-145.

Horan, B., P. Dillon, P. Faverdin, L. Delaby, F. Buckley, and M. Rath. 2005. The interaction of strain of Holstein-Friesian cows and pasture based feed systems on milk yield, body weight, and body condition score. J. Dairy Sci. 88:1231-1243.

Humphreys, J., I. A. Casey, and O. T. Carton. 2003. Meeting environmental objectives and potential constraint on dairy production in Ireland. Pages 145-164 in Nutrient Management at Farm Scale: Attaining Policy Objectives in Regions with Intensive Dairy Farming. Proceedings of European Grassland Federation International Workshop on Agricultural and Environmental Issues. Quimper, France. Plant Research International, Wageningen, the Netherlands.

Humphreys, J., I. A. Casey, P. Darmody, K. O'Connell, O. Fenton, and C. J. Watson. 2008. Soil mineral N and nitrate-N losses to groundwater from four grassland-based systems of dairy production on a clay loam-soil under moist temperature climatic conditions. Grass Forage Sci. 63:481-494.

Jarvis, S., N. Hutchings, F. Brentrup, J. E. Olesen, and K. W. van de Hoek. 2011. Nitrogen flows in farming systems across Europe. Pages 221-228 in The European Nitrogen Assessment. M. A. Sutton, C.M. Howard, J. W. Erisman, G. Billen, A. Bleeker, P. Grennfelt, H. van Grinsven, and B. Grizzetti, ed. Cambridge University Press, Cambridge, UK.
Jonker, J. S., R. A. Kohn, and R. A. Erdman. 1998. Using milk urea nitrogen to predict nitrogen excretion and utilization efficiency in lactating dairy cows. J. Dairy Sci. 81:2681-2692.

Kelly, E., L. Shalloo, U. Geary, A. Kinsella, F. Thorne, and M. Wallace. 2012. The associations of management and demographic factors with technical, allocative and economic efficiency of Irish dairy farms. J. Agric. Sci. 150:738-754.

Kennedy, E., M. McEvoy, J. P. Murphy, and M. O'Donovan. 2009 Effect of restricted access time to pasture on dairy cow milk production, grazing behaviour, and dry matter intake. J. Dairy Sci. 92:168-176.

Kurunc, A., S. Ersahin, B. Yetgin Uz, N. K. Sonmez, I. Uz, H. Kaman, G. E Bacalan, and Y. Emekli. 2011. Identification of nitrate leaching hot spots in a large area with contrasting soil texture and management. Agric. Water Manage. 98:1013-1019.

Laidlaw, A. S., and C. S. Mayne. 2000. Setting management limits for the production and utilization of herbage for out-of-season grazing. Grass Forage Sci. 55:14-25.

Ledgard, S. F., J. W. Penno, and M. S. Sprosen. 1997. Nitrogen balances and losses on intensive dairy farms. Pages 49-53 in Proc. N.Z. Grassl. Assoc. Vol. 59. NZ Grassland Association Inc., Dunedin, New Zealand.

Ledgard, S. F., J. W. Penno, and M. S. Sprosen. 1999. Nitrogen inputs and losses from clover/grass pastures grazed by dairy cows, as affected by nitrogen fertilizer application. J. Agric. Sci. 132:215225

Lips, M., and P. Reider. 2005. Abolition of raw milk quota in the $\mathrm{Eu}-$ ropean Union: A CGE analysis at the member country level. J. Agric. Econ. 56:1-17.

Macdonald, K. A., J. W. Penno, J. A. S. Lancaster, and J. R. Roche. 2008. Effect of stocking rate on pasture production, milk production and reproduction of dairy cows in pasture-based systems. J. Dairy Sci. 91:2151-2163.

McCarthy, B., L. Delaby, K. M. Pierce, A. Brennan, and B. Horan. 2013b. The effect of stocking rate and calving date on milk production of Holstein-Friesian dairy cows. Livest. Sci. 153:123-134.

McCarthy, B., L. Delaby, K. M. Pierce, F. Journot, and B. Horan. 2011. Meta-analysis of the impact of stocking rate on the productivity of pasture-based milk production systems. Animal 5:784794.

McCarthy, B., K. M. Pierce, L. Delaby, A. Brennan, C. Fleming, and B. Horan. 2013a. The effect of stocking rate and calving date on grass production, utilization and nutritive value of the sward during the grazing season. Grass Forage Sci. 68:364-377.

McCarthy, S., B. Horan, P. Dillon, P. O'Connor, M. Rath, and L. Shalloo. 2007. An economic comparison of three divergent strains of Holstein-Friesian dairy cows in various pasture based milk production systems. J. Dairy Sci. 90:1493-1505.

McDonald, R., K. Pierce, R. Fealy, and B. Horan. 2013. Characteristics, intentions and expectations of new entrant dairy farmers entering the Irish dairy industry through the New Entrant Scheme. Inter. J. Agric. Manag. 2:189-198.

Mihailescu, E., P. N. C. Murphy, W. Ryan, I. A. Casey, and J. Humphries. 2014. Nitrogen balance and use efficiency on twentyone intensive grass-based dairy farms in the south of Ireland. J. Agric. Sci. 152:843-859.

Moir, J. L., B. J. Malcolm, K. C. Cameron, and H. J. Di. 2012. The effect of dicyandiamide on pasture nitrate concentration, yield and $\mathrm{N}$ offtake under high $\mathrm{N}$ loading in winter and spring. Grass Forage Sci. 67:391-402.

Monaghan, R. M., L. C. Smith, and S. F. Ledgard. 2009. The effectiveness of a granular formulation of dicyandiamide (DCD) in limiting nitrate leaching from a grazed dairy pasture. N. Z. J. Agric. Res. $52: 145-159$

National Farm Survey (NFS). 2012. National Farm Survey Report. Teagasc, Rural Economy Research Centre, Galway, Ireland. Accessed Apr. 5, 2014. http://www.teagasc.ie/nfs/.

O'Connell, K., J. Humphreys, and C. J. Watson. 2004. Quantification of nitrogen sources for grassland. Pages 15-28 in Winter Scientific Meeting. The Fertiliser Association of Ireland. Grassland Fertilizers Ltd., Cork, Ireland. 
O'Connor, P. J., D. Hennessy, M. B. Lynch, H. Slattery, and E. Lewis. 2013. The effect of dicyandiamide on rumen and blood metabolites, diet digestibility and urinary excretion. Livest. Sci. 155:30-37.

O'Donnell, S., L. Shalloo, A. M. Butler, and B. Horan. 2008. A survey analysis of opportunities and limitations of Irish dairy farmers. J. Farm Manag. 13:1-15.

O'Donovan, M. 2000. The relationship between the performance of dairy cows and grassland management on intensive dairy farms in Ireland. PhD thesis. National University of Ireland, Dublin, Ireland.

Peyraud, J. L., and L. Delaby. 2006. Grassland management with emphasis on nitrogen flows. Pages 103-123 in Fresh Herbage for Dairy Cattle. A. Elgersma, J. Dijkstra, and S. Tamminga, ed. Wageningen UR Frontis Series No.18. Wageningen UR, Wageningen, the Netherlands.

Premrov, A., C. E. Coxon, R. Hackett, L. Kirwan, and K. G. Richards 2012. Effects of over-winter green cover on groundwater nitrate and dissolved organic carbon concentrations beneath tillage land. Sci. Total Environ. 438:144-153.

Pretty, J. N. 1997. The sustainable intensification of agriculture. Nat. Resour. Forum 21:247-256. (United Nations Published by Elsevier Science Ltd.).

Ramsbottom, G., A. R. Cromie, B. Horan, and D. P. Berry. 2012 Relationship between dairy cow genetic merit and profit on commercial spring calving dairy farms . Animal 6:1031-1039.

Richards, K. G., C. Coxon, M. Ryan, D. Daly, and J. Kiely. 1996. Quantification of nitrate leaching to groundwater. Ir. J. Agric. Food Res. 35:67 (Abstract).

Richards, K. G., O. Fenton, M. I. Khalil, A. Haria, J. Humphreys, D. Doody, R. Moles, G. Morgan, and P. Jordan. 2009. Good water status: The integration of sustainable grassland production and water resources in Ireland. Tearmann 7:143-160.

Royal Society. 2009. Reaping the benefits: Science and the sustainable intensification of global agriculture. Royal Society, London, UK.

Ryan, M., C. Brophy, J. Connolly, K. McNamara, and O. T. Carton. 2006. Monitoring of nitrogen leaching on a dairy farm during four drainage seasons. Ir. J. Agric. Food Res. 45:115-134.

Ryan, W., D. Hennessy, J. J. Murphy, T. M. Boland, and L. Shalloo, 2011. A model of nitrogen efficiency in contrasting grass based dairy systems. J. Dairy Sci. 94:1032-1044.

Ryan, W., D. Hennessy, J. J. Murphy, T. M. Boland, and L. Shalloo. 2012. The effect of grazing season length on nitrogen utilisation, efficiency and nitrogen balance in spring calving dairy production systems. J. Agric. Sci. 150:630-643.

SAS Institute. 2006. SAS User's Guide: Statistics. Version 9.1. SAS Institute Inc., Cary, NC.

Schulte, R. P. O., J. Diamond, K. Finkele, N. M. Holden, and A. J. Brereton. 2005. Predicting the soil moisture conditions of Irish grasslands. Ir. J. Agric. Food Res. 44:95-110.
Shalloo, L., P. Creighton, and M. O'Donovan. 2010. Reseeding. A cost or an opportunity. Pages139-151 in Proc. Grasses for the Future International Conf., Teagasc, Cork, Ireland.

Shalloo, L., J. Kennedy, M. Wallace, M. Rath, and P. Dillon. 2004. The economic impact of cow genetic potential for milk production and concentrate supplementation level on the profitability of pasture based systems under different EU milk quota scenarios. J. Agric. Sci. 142:357-369.

Shani, U., A. Ben-Gal, E. Tripler, and L. M. Dudley. 2007. Plant response to the soil environment: An analytical model integrating yield, water, soil type, and salinity. Water Resour. Res. 43:W08418 http://dx.doi.org/10.1029/2006WR005313.

Sprosen, M. S., S. F. Ledgard, S. B. Lindsey, and K. A. Macdonald. 2002. Effect of stocking rate on leaching of nitrate and associated nutrients. Pages 183-188 in: Dairy Farm Soil Management. Occasional Report No. 15. L. D. Currie and P. Loganathan, ed. Fertilizer and Lime Research Centre, Massey University Palmerston North, New Zealand.

Stark, C. H., and K. G. Richards. 2008. The continuing challenge of agricultural nitrogen loss to the environment in the context of global change and advancing research. Dyn. Soil Dyn. Plant $2: 1-12$.

Tamminga, S. 1992. Nutrition management of dairy cows as a contribution to pollution control. J. Dairy Sci. 75:345-357.

Tas, B. M., H. Z. Taweel, H. J. Smit, A. Elgersma, J. Dijkstra, and S. Tamminga. 2006. Effects of perennial ryegrass cultivars on milk yield and nitrogen utilization in grazing dairy cows. J. Dairy Sci 89:3494-3500

Teagasc. 2009. Grazing notebook, recommended nitrogen rates and timings throughout the grazing season. Cork, Ireland. http://www. agresearch.teagasc.ie/moorepark/Publications/pdfs/Open\%20 Day\%20Moorepark\%202009\%20Grazing\%20Manual.pdf.

Treacy, M., J. Humphreys, K. McNamara, R. Browne, and C. J. Watson. 2008. Farm-gate nitrogen balances on intensive dairy farms in the south west of Ireland. Ir. J. Agric. Food Res. 47:105-117.

Valentine, S., P. Lewis, R. T. Cowan, and J. Defaveri. 2009. The ef fects of high stocking rates on milk production from dryland and irrigated Mediterranean pastures. Anim. Prod. Sci. 49:100-111.

Watson, C. A., and D. Atkinson. 1999. Using nitrogen budgets to indicate nitrogen use efficiency and losses from whole farm systems: A comparison of three methodological approaches. Nutr. Cycl. Agroecosyst. 53:259-267.

Webster, C. P., M. A. Shepherd, K. W. T. Goulding, and E. Lord 1993. Comparisons of methods for measuring the leaching of mineral nitrogen from arable land. J. Soil Sci. 44:49-62.

Whitehead, D. C. 1995. Mineralization, immobilization and availability of nitrogen in soils. Pages 108-128 in Grassland Nitrogen. CAB International, Wallingford, UK. 